\title{
Postsynaptic Potentials Mediated by GABA and Dopamine Evoked in Stellate Glial Cells of the Pituitary Pars Intermedia
}

\author{
Lori A. Mudrick-Donnon, Peter J. Williams, Quentin J. Pittman, and Brian A. MacVicar \\ Neuroscience Research Group, University of Calgary, Calgary, Alberta, Canada T2N 4N1
}

Studies have shown that many glial cells in the CNS possess receptors for neurotransmitters and that synapse-like contacts exist between glial cells and axonal terminals. Although synapse-like contacts are present between the glial cells (stellate cells) of the pituitary pars intermedia and the axons from the arcuate nucleus, it is not known whether these cells are under synaptic control. The objective of the present study was to determine whether transmitter-mediated postsynaptic potentials occurred in the stellate cells of the rat pituitary pars intermedia. Whole pituitaries were maintained in vitro, and a stimulating electrode was placed on the stalk to activate afferent fibers. Intracellular recordings were obtained with sharp microelectrodes. Stellate cells showed electrophysiological characteristics of macroglia including a resting potential more negative than $-65 \mathrm{mV}$, low input resistance ( $<50 \mathrm{M} \Omega$ ), and no detectable voltage-activated conductances. Single-pulse afferent nerve (stalk) stimulation evoked a $\left[\mathrm{Ca}^{2+}\right]_{0}$-dependent postsynaptic response in the stellate cells consisting of a depolarization ( $<500 \mathrm{msec}$ ) and a long-lasting hyperpolarization (45-75 sec). The depolarization was mimicked by GABA application and blocked by the $\mathrm{GABA}_{\mathrm{A}}$ antagonist bicuculline $(100 \mu \mathrm{M})$. Repetitive stimulation of the stalk increased the amplitude and prolonged the GABA-mediated depolarization, during which a decrease in input resistance was observed. The hyperpolarization was mimicked by dopamine and blocked by the $D_{2}$ antagonists sulpiride $(2 \mu \mathrm{M})$ and domperidone $(10 \mu \mathrm{M})$. Nipecotic acid ( $100 \mu \mathrm{M}$; an inhibitor of GABA uptake) or GBR 12909 (15 $\mu \mathrm{M}$; an inhibitor of dopamine uptake) had minimal effects on the synaptic responses. Following electrophysiological recording, neurobiotin was injected into the impaled stellate cells and subsequently visualized with streptavidinaminomethylcoumarin fluorescence. The tissue was then immunostained for glial fibrillary acidic protein and visualized with Texas red fluorescence. Positive double staining was observed in all injected stellate cells from which postsyn-

\footnotetext{
Received Jan. 20, 1993; revised May 20, 1993; accepted May 27, 1993.

P.J.W. and L.A.M-D contributed equally to the experimental work presented in this article. The study was supported by the Medical Research Council (MRC) of Canada. P.J.W. is an MRC Postdoctoral Fellow. L.A.M-D. is an Alberta Heritage Foundation for Medical Research (AHFMR) and MRC Postdoctoral Fellow. Q.J.P. is an AHFMR Scientist, and B.A.M. is an AHFMR Scholar and MRC Scientist. We extend thanks and appreciation to Dr. Keith Sharkey for his generosity in allowing us to use his anatomical facilities. We also thank Drs. Ray Turner, Katja Hoehn, Jonathan Coles, Thierry Amédée, and Steve Duffy for their valuable comments on the manuscript.

Correspondence should be addressed to Dr. Lori Mudrick-Donnon, Neuroscience Research Group, University of Calgary, 3330 Hospital Drive Northwest, Calgary, Alberta, Canada T2N $4 \mathrm{~N} 1$.

Copyright @ 1993 Society for Neuroscience $0270-6474 / 93 / 134660-09 \$ 05.00 / 0$
}

aptic potentials had been recorded. These data provide the first demonstration of neurotransmitter-mediated postsynaptic potentials in vertebrate glial cells.

[Key words: glial fibrillary acidic protein, stellate cells, synaptic potentials, GABA, dopamine, pituitary pars intermedia, astroglia]

Recent electrophysiological investigations using in vitro preparations such as dissociated cultures, hippocampal slices, and the intact retina have shown that glial cells possess receptors for many neurotransmitters including glutamate (Sontheimer et al., 1988; Usowicz et al., 1989; Cull-Candy and Wyllie, 1991), GABA (Kettenmann et al., 1987; MacVicar et al., 1989; Clark and Mobbs, 1992), and noradrenaline (Hösli et al., 1982; Harumitsu et al., 1983; Hirata et al., 1983). It is not known, howcver, whether transmitter released from axonal terminals can activate a "postsynaptic" response in glial cells. In the PNS of the squid, apparent transmitter release can modulate membrane potential (Lieberman et al., 1989; Evans et al., 1990) and induce changes in intracellular calcium concentration in Schwann cells adjacent to synapses (Jahromi et al., 1992; Reist and Smith, 1992). Marrero et al. (1989) have reported that nerve impulses in the axons of the frog optic nerve can alter transiently the properties of the voltage-dependent membrane channels of astrocytes. Interestingly, synapse-like contacts between axonal terminals and glial cells have been reported in astrocytes of the cerebral cortex (Aoki, 1992), tanycytes lining the third ventricle (Card and Moore, 1985; Bosler et al., 1987), and pituicytes of the posterior pituitary (Baumgarten et al., 1972). Of particular interest for the present study is the observation that axonal projections from the cells of the arcuate nucleus form synaptic or synaptoid contacts on the stellate glial cells of the pituitary pars intermedia (Stoeckel et al., 1981; Oertel et al., 1982; de Rijk, 1990).

The rat pars intermedia is a relatively homogeneous structure that is comprised primarily of melanocytes and stellate cells (Wingstrand, 1966; Weatherhead, 1983). Melanocytes, the principle cell type of the pars intermedia, are small secretory cells without processes and contain neuron-specific enolase (Schmechel et al., 1978). In contrast, stellate cells have a shape similar to astroglia with numerous radiating processes that form a complex network throughout the pars intermedia parenchyma (Stoeckel et al., 1981; Weatherhead, 1983). They react strongly with antisera to glial fibrillary acidic protein (GFAP) (Stoeckel et al., 1981; Ordronneau and Petrusz, 1986) but do not contain neuron-specific enolase (Schmechel et al., 1978).

It is possible to isolate the whole rat pituitary with the infundibular stalk intact and maintain it in vitro for electrophysiological investigation (MacVicar and Pittman, 1986). The stalk- 
attached whole pituitary provides an attractive preparation to examine the possible postsynaptic physiology of glial cells, as the pars intermedia is without any form of interneuron and melanocytes are without dendrites or axons, meaning that recurrent collaterals could not generate complex polysynaptic interactions. The fact that synapse-like contacts exist between stellate cells and axonal terminals from the arcuate nucleus suggests that the stellate cells may be under direct synaptic control. The objectives of the present study, therefore, were to (1) investigate the morphological characteristics of stellate cells of the pars intermedia by intracellular labeling with neurobiotin, (2) confirm their glial nature by immunohistochemical localization of GFAP, (3) determine the electrophysiological characteristics of stellate cells, and (4) examine possible postsynaptic actions following stalk stimulation. The results show that stellate cells of the pars intermedia stain positively with GFAP, demonstrate electrophysiological characteristics of macroglia, and, most importantly, exhibit postsynaptic potentials following activation of the pituitary stalk.

\section{Materials and Methods}

Tissue preparation. The stalk-attached whole pituitary preparation was used as described previously (MacVicar and Pittman, 1986). Anesthetized male Sprague-Dawley rats $(250-400 \mathrm{gm})$ were decapitated, the cranium and dura were removed, and the brainstem was lifted gently while the cranial nerves were severed. The exposed infundibular stalk was cut close to the hypothalamus and the overlying brain tissue removed. The pituitary was bathed with oxygenated artificial cerebrospinal fluid (aCSF) while the diaphragma sellae was cut away. The freed pituitary was then transferred quickly to a recording chamber where it was superfused at a rate of $1 \mathrm{ml} / \mathrm{min}$ with aCSF containing (mM) NaCl, 124; $\mathrm{KCl}, 5 ; \mathrm{NaICO}_{3}, 26.2 ; \mathrm{CaCl}_{2}, 2 ; \mathrm{MgCl}_{2}, 1.3$; and D-glucose, 10 . The solution was gassed continuously with $95 \% \mathrm{O}_{2}, 5 \% \mathrm{CO}_{2}$ to give a $\mathrm{pH}$ of 7.4 and maintained at $32-33^{\circ} \mathrm{C}$. The pituitary was anchored by resting two pieces of stainless steel tubing, held in a manipulator, on the pars distalis. A bipolar stimulating electrode (twisted Teflon-coated silver wire, $0.19 \mathrm{inch}$ ) was placed on the stalk to activate afferent fibers.

Drug application. Bicuculline methiodide (100 $\mu \mathrm{M}$; Sigma), sulpiride ( $2 \mu \mathrm{M}$; Sigma), nipecotic acid (10 $\mu \mathrm{M}$; Sigma), domperidone $(10 \mu \mathrm{M}$; a gift from Janssen Pharmaceuticals), and GBR 12909 (15 $\mu$ M; Research Biochemicals Inc.) were added directly to the aCSF flowing into the recording chamber to give final concentrations as indicated. $\gamma$-Amino$n$-butyric acid (GABA) (Sigma; $1 \mathrm{~mm}$ in aCSF) and dopamine- $\mathrm{HCl}$ (Sigma; $1 \mathrm{~mm}$ in aCSF containing $10 \mathrm{mg} /$ liter sodium metabisulfite as an antioxidant) were applied by pressure pulses (5-10 psi, 10-300 msec) from a multichannel Picospritzer (General Valve Corp.), to a threcbarrel micropipette located adjacent to the cell under study. Multibarreled electrodes were built by securing three pieces of thin-walled glass [1.5 mm o.d.; World Precision Instruments (WPI)] with shrink tubing and pulling with a double pull protocol to give a fused sharp tip. The tip was broken to give a tip diameter of 3-5 $\mu \mathrm{m}$ for each barrel. One barrel of the pipette always contained the vehicle as a control and the position of the pipette was adjusted so that pulses of the vehicle did not produce an electrophysiological response. When low-Ca ${ }^{2+} /$ high$\mathrm{Mg}^{2+}$ aCSF was used, it contained (mM) $\mathrm{NaCl}, 126 ; \mathrm{KCl}, 5 ; \mathrm{NaHCO}_{3}$, $26.2 ; \mathrm{CaCl}_{2}, 0.1 ; \mathrm{MgCl}_{2}, 2.6$; and D-glucose, 10 .

Recording techniques. Intracellular recording electrodes were pulled from thin-walled glass (1.5 mm o.d.; WPI) on a Flaming-Brown micropipette puller (model P-87, Sutter Instrument Co.) and filled with $0.5 \mathrm{M} \mathrm{K}^{+}$-acetate $(70-100 \mathrm{M} \Omega)$. Electrodes contained $2 \%$ ncurobiotin (Vector Labs) in $0.5 \mathrm{M} \mathrm{K}^{+}$-acetate for intracellular labeling of the impaled cells. Under visual control the electrodes were directed toward the caudal pars intermedia opposite to the stalk. The pars intermedia was identified easily as a lobular, capillary-free zone between the pars distalis and the pars nervosa. Afferent fibers were activated either by single-pulse stimulation $(0.5-15 \mathrm{~V}, 300-1000 \mu \mathrm{sec})$, by a short stimulus train (10 pulses, $1 \mathrm{msec}$ pulse width, $500 \mathrm{msec}$ duration) or, in some experiments, by repetitive stalk stimulation for $4 \mathrm{sec}(10 \mathrm{~V}, 1 \mathrm{msec}$ pulse width, $20 \mathrm{~Hz}$ ) from a digital pulse generator (Getting). Intracellular potentials were amplified conventionally with the Unity-gain headstage amplifier (HS-2L) of an Axoclamp-2 microelectrode clamp (Axon Instruments, Inc.). Signals were digitized with a Neuro-corder (Neuro Data Instruments Corp.) and stored on videotape, or digitized with a Labmaster A/D converter board and the TL-1 interface (Axon Instruments, Inc.) and stored on line on the hard disk of a microcomputer (Packard Bell 386, AXOTAPE software). Current-voltage relationships were determined using pulse protocols generated with pCLAMP software (Axon Instruments, Inc.).

Neuron identification and GFAP immunohistochemistry. Following electrophysiological recording, the cells were injected with neurobiotin (1-1.5 $\mathrm{nA}, 150 \mathrm{msec}, 3.3 \mathrm{~Hz}, 10-12 \mathrm{~min}$ ) and the whole pituitary was transferred to Zamboni's fixative (15\% saturated picric acid, $2 \%$ paraformaldehyde, in $0.1 \mathrm{~m}$ phosphate buffer, $\mathrm{pH} 7.4$ ) for $18 \mathrm{hr}$. The tissue was then stored in $30 \%$ sucrose (in $0.1 \mathrm{M}$ phosphate buffer) for $1-5 \mathrm{~d}$ before cutting. Serial sections $(20 \mu \mathrm{m})$ were cut in a cryostat and mounted directly onto microscope slides coated with poly-D-lysine (Sigma). The slides were then stored at $4^{\circ} \mathrm{C}$ for $1-2 \mathrm{~d}$ until processing. The protocol used for visualization of the cells filled with neurobiotin and GFAP immunohistochemistry was similar to that described by Rønnekleiv et al. (1990) except for the following changes. Phosphate-buffered saline (0.1 M, pH 7.6) was substituted for phosphate buffer. The liquid nitrogen freeze-thaw technique (Leranth and Feher, 1983) was used prior to staining and the slides were rinsed in phosphate buffered saline containing $0.4 \%$ Triton $X-100$ for $30 \mathrm{~min}$. A streptavidin-aminomethylcoumarin (AMCA) conjugate [1:500, Jackson Immunoresearch Laboratories (IIL)] was used to label the neurobiotin. Donkey serum $(50 \%$; JIL) was applied for $2 \mathrm{hr}$ prior to the primary antibody and $20 \mathrm{~min}$ prior to the secondary antibody. The anti-GFAP antiserum $(1: 1000)$ was raised in rabbit to human MS-plaque GFAP (a kind gift from Dr. L. F. Eng, Stanford University, Veterans Affairs Medical Center) and applied for $3 \mathrm{~d}$ at $4^{\circ} \mathrm{C}$. A donkey anti-rabbit IgG-Texas red conjugate (1:50; JIL) was used to visualize the bound GFAP antibody. Fluorescence was viewed with a Zeiss Axioplan microscope with a UV G385 filter set for AMCA fluorescence and a Green H546 filter set for Texas red fluorescence.

\section{Results}

\section{Histology of the pars intermedia}

The rat pituitary consists of three anatomically distinct regions that can be delineated easily in histological sections and in the in vitro pituitary preparation. The pars distalis forms the bulk of the pituitary and is separated from the pars intermedia by the pituitary cleft. The "plexus intermedius," a plexus of capillaries attached to a basement membrane, separates the pars intermedia from the pars nervosa (Fig. $1 A$ ). The pars intermedia is divided into circular lobules (diameter of $150-325 \mu \mathrm{m}$ ) by septa that run from the pituitary cleft to the plexus (Fig. $1 A, G$ ). Each lobule is populated by numerous melanocytes (diameter of $\sim 11 \mu \mathrm{m}$ ) and a small population of stellate cells (Fig. $1 B, C$ ). The stellate cells have large cell bodies (diameter of $\sim 21 \mu \mathrm{m}$ ) and form an extensive network of radiating processes throughout the pars intermedia parenchyma.

\section{Neurobiotin injections}

Neurobiotin filled the cytoplasmic volume of every cell that was injected with the label and showed that the cells demonstrating glial-like electrophysiological properties (discussed below) had a morphology consistent with that of stellate cells of the pars intermedia (Fig. $1 D, E$ ). There was extensive dye transfer between the stellate cells as indicated by the numerous cell bodies labeled. An extensive network of processes could be observed not only within the lobule housing the cell from which recordings were made, but also within adjacent lobules (Fig. $1 D, E$ ). In contrast, when cells demonstrating electrophysiological properties of melanocytes (discussed below) were injected with neurobiotin, only a single small cell without processes was labeled (Fig. $1 F$ ). 
A

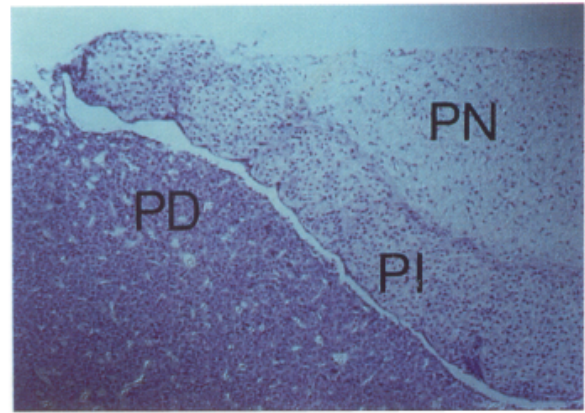

(

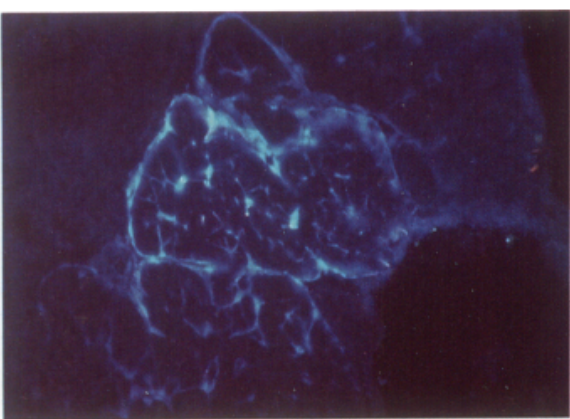

0

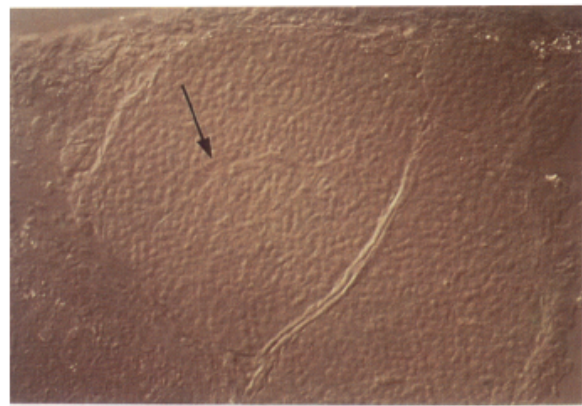

v

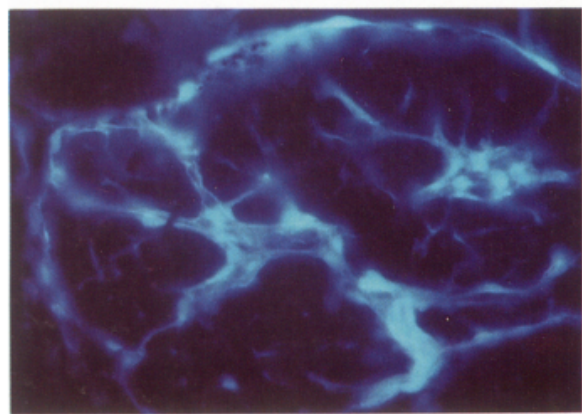

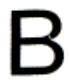
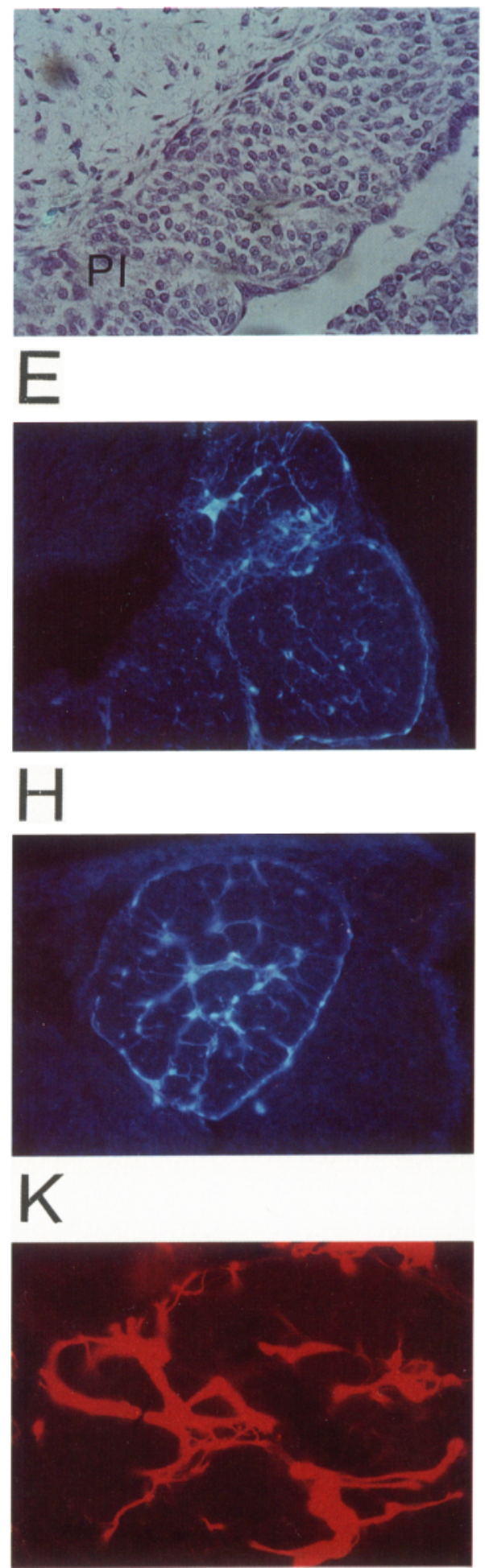

C
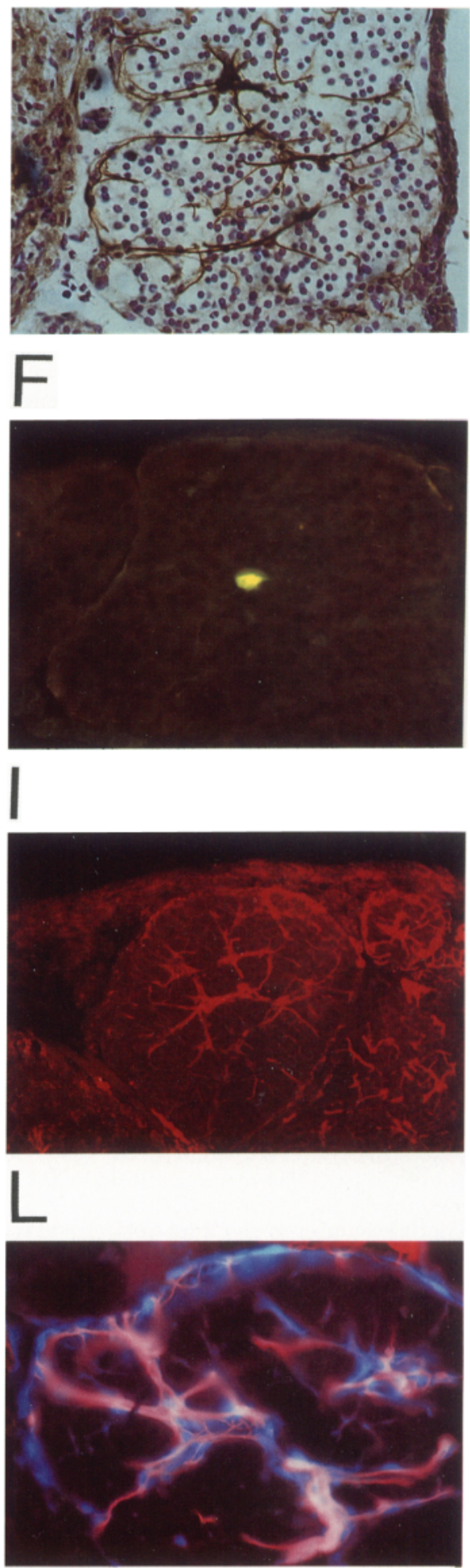

Figure 1. Histological characteristics of the pituitary pars intermedia, neurobiotin visualization, and localization of GFAP in stellate cells. $A$ and $B$ show Nissl-stained sections of the pituitary to illustrate the homogeneous appearance of the pars intermedia. $A$, The pars intermedia $(P I)$ juxtaposes the pars nervosa $(P N)$ but is separated from the pars distalis $(P D)$ by the pituitary cleft $(46 \times$ magnification). In the pars intermedia, five lobules can be discerned. $B$, The Nissl stain illustrates the numerous melanocyte nuclei of the pars intermedia ( $186 \times$ magnification). $C$ shows both prominent cell types of the PI (186 × magnification). The small Nissl-stained cells are melanocytes that do not have processes. The brown stain localizes GFAP in the stellate cells (visualized with 3,3'-diaminobenzidine) illustrating large somata and numerous radiating processes. $D$ and $E$ show two examples of neurobiotin staining in stellate cells (visualized with streptavidin-AMCA) after electrophysiological analysis and subsequent iontophoresis of neurobiotin ( $93 \times$ magnification). Neurobiotin has spread extensively and filled numerous cells and processes. The extensive dye coupling can also be observed between adjacent lobules (intense staining outlines the perimeter of each). $F$ illustrates a melanocyte injected with neurobiotin and visualized with streptavidin-FITC $(1: 300 ; \mathrm{JIL})$. Note the lack of processes and the lack of dye coupling (186 $\times$ magnification). $G-I$ illustrate one 


\section{GFAP immunohistochemistry}

GFAP, the predominant protein of intermediate filaments in astroglia (Eng, 1985), was localized immunohistochemically within the stellate cells of the pars intermedia and the pituicytes of the pars nervosa but not in the pars distalis (Fig. 1C,I). In the pars intermedia radiating processes could be observed interwoven throughout the parenchyma of melanocytes (Fig. $1 \mathrm{C}$ ). The perimeter of each lobule could usually be identified by the intense staining of processes from the numerous stellate cells within the lobule (Fig. $1 I, K$ ). Although GFAP antiserum seemed to label the entire stellate cell population, neurobiotin was confined to a small cell population, presumably those coupled to the injected cell (Fig. $1 G-I$ ). Controls in which the primary antiserum was omitted did not exhibit staining with GFAP. Positive double staining with neurobiotin and GFAP (Fig. $1 H-$ $L$ ) was observed in all neurobiotin-injected stellate cells from which postsynaptic potentials had been recorded $(n=6)$.

\section{Membrane properties}

To demonstrate that the electrophysiological responses recorded in stellate cells were indeed from a population of cells different from melanocytes, the membrane and synaptic properties of these two cell types were compared. Melanocytes were impaled much more frequently than stellate cells and demonstrated membrane properties that have been well documented (Douglas and Taraskevich, 1978, 1980; MacVicar and Pittman, 1986). These included membrane potentials between -30 and -50 $\mathrm{mV}$ and high input resistances (300-1200 M 2 ). Depolarizing current injection activated action potentials and a number of conductances in melanocytes. The membrane properties of the stellate cells were quite distinct from those of melanocytes but typical of glial cells (Walz, 1989). Stellate cells had resting membrane potentials more negative than $-65 \mathrm{mV}$ with a mean of $-76 \pm 5 \mathrm{mV}$ (mean $\pm \mathrm{SD}, n=33$ ) and low input resistance $(33 \pm 14 \mathrm{M} \Omega)$. The stellate cells did not appear to possess voltage-activated conductances over the membrane potentials tested and showed only a passive response to current injection of up to $500 \mathrm{pA}$ (Fig. 2A).

\section{Synaptic physiology}

Postsynaptic potentials could always be evoked in melanocytes and stcllatc cclls cxcept when tissue dissection had caused the infundibular stalk to be stretched. In melanocytes, stalk stimulation has been shown to evoke both an initial GABA-mediated IPSP and a slower, small-amplitude hyperpolarization mediated by dopamine (MacVicar and Pittman, 1986; Williams et al., 1989a,b). Stellate cells also responded to stalk stimulation with postsynaptic potentials, but the response was different from the response recorded typically from the melanocytes. An increase in the intensity of stimulation increased both the amplitude and duration of the responses. Single-pulse stimulus evoked
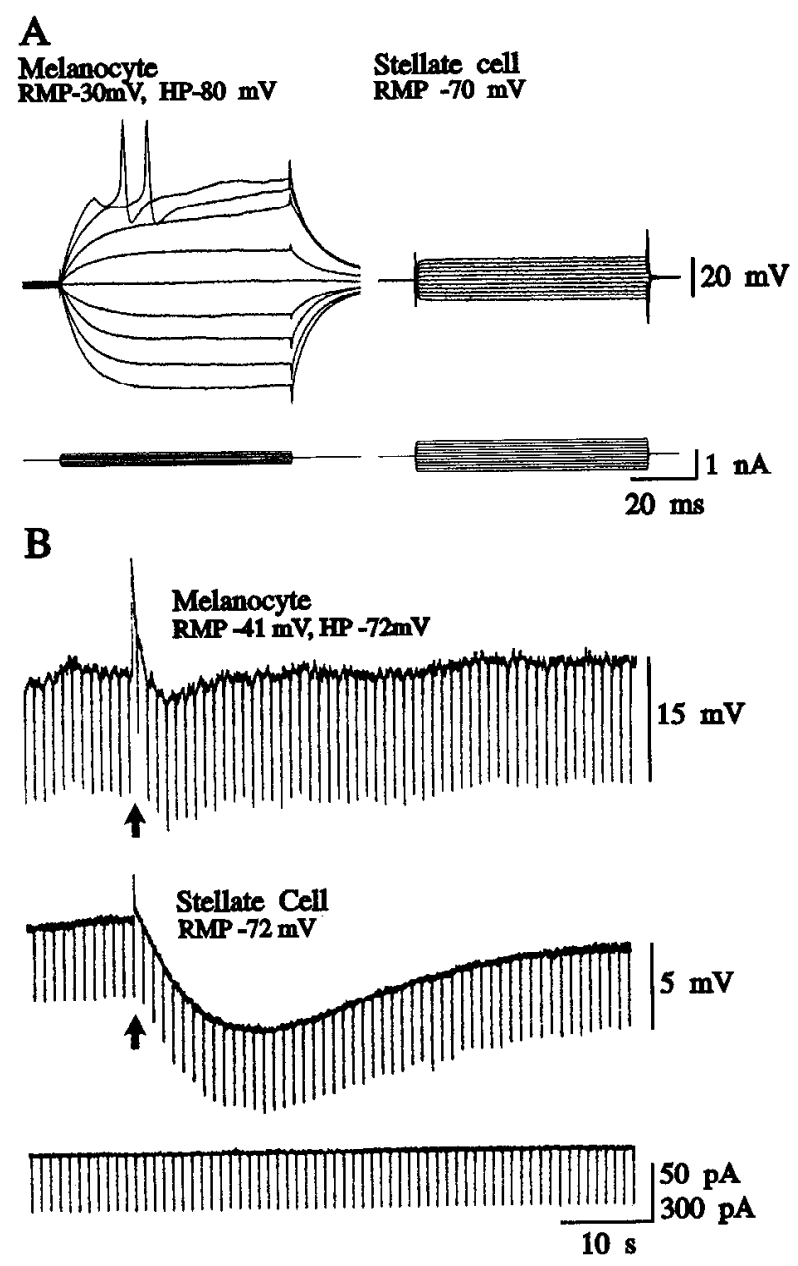

Figure 2. Membrane characteristics and synaptic responses of stellate cells and melanocytes. $A$, Intracellular recordings to illustrate the voltage changes (upper traces) produced by injecting a family of current pulses (lower traces) through the recording electrode. The steady state hyperpolarizing voltage deflection was used to calculate input resistance. $\mathrm{Me}$ lanocyle, Current steps (90 msec, 50 pA increments) ranged from -200 $\mathrm{pA}$ to $+200 \mathrm{pA}$, giving a calculated input resistance of $300 \mathrm{M} \Omega$. Action potentials were evoked by the injection of depolarizing current. Stellate cell, Current steps ( $90 \mathrm{msec}, 100 \mathrm{pA}$ increments) ranged from $-500 \mathrm{pA}$ to $+500 \mathrm{pA}$, giving a calculated input resistance of $25 \mathrm{M} \Omega$. Note the lack of apparent voltage-activated conductances in the stellate cell membrane over this limited range of potentials. B:Melanocyte, Single-pulse stimulation of the pituitary stalk (arrow) evoked an initial depolarization (GABA mediated) followed by a hyperpolarization [dopamine mediated; see MacVicar and Pittman (1986) for details]. Stellate cell, Singlepulse stalk stimulation (arrow) also evoked a postsynaptic response with two components. The initial depolarizing response was of much shorter duration and was smaller in amplitude than that observed in the melanocytes. The hyperpolarizing response was much greater in amplitude and longer in duration and in some cells could still be observed after $80 \mathrm{sec}$. Lower trace indicates the current pulses injected throughout the experiments. Upper calibration value corresponds to current injected into the melanocyte; the lower corresponds to that injected into the stellate cell.

\section{$\leftarrow$}

photographic field of the pars intermedia observed with Nomarski optics $(G)$ and filters for AMCA $(H)$ and Texas red $(I)$ fluorescence $(93 \times$ magnification). $G$, Nomarski optics show the septa separating the pars intermedia into lobules, the numerous round melanocytes, and a stellate cell (arrow) weaving through the melanocyte parenchyma. $H$, The neurobiotin injection is confined to one lobule, but extensive dye coupling can be observed between the neurobiotin-injected cell and a number of other stellate cells. $I$, GFAP immunostaining is positive in stellate cells throughout the pars intermedia, and there is extensive overlap with the cells and processes labeled with neurobiotin. Positive staining can also be observed in the pituicytes of the pars nervosa (lower left corner). $J-L$ show the same photographic field (186× magnification). $J$ illustrates a neurobiotin-injected stellate cell visualized with AMCA, $K$ shows positive GFAP staining in the same cell visualized with Texas red, and $L$ is a double photographic exposure to identify positive double staining and the overlap of the neurobiotin and GFAP staining. The electrophysiology and synaptic properties of this cell are shown in Figure 3. 


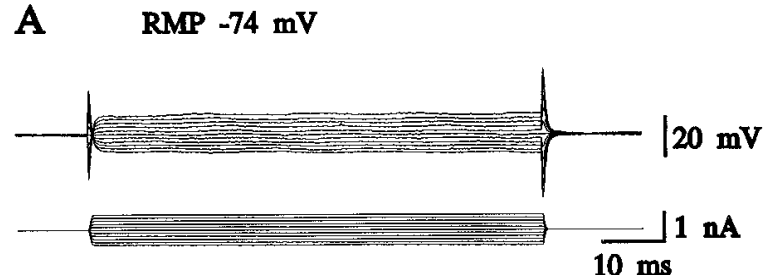

B
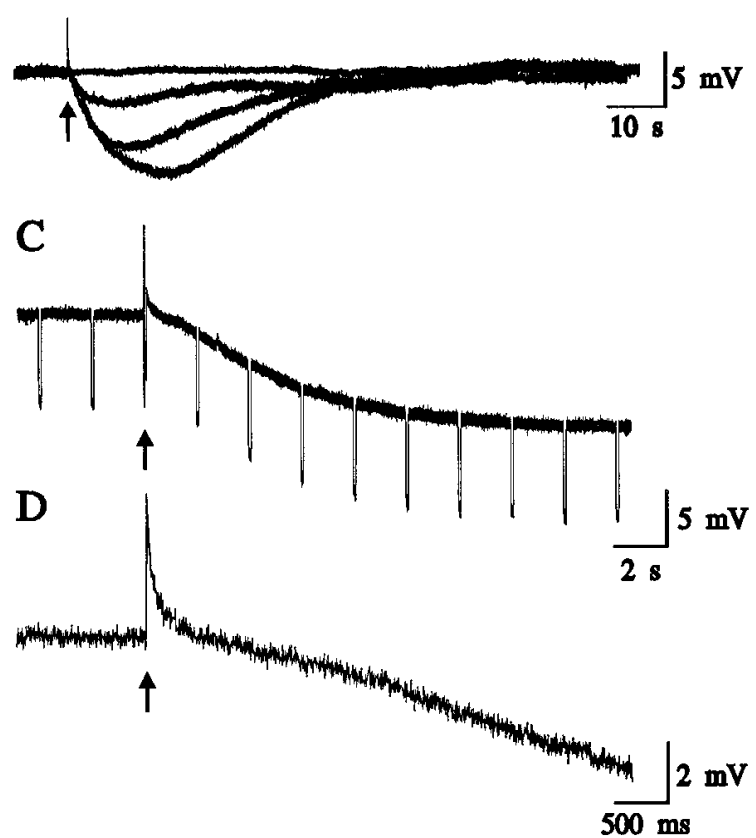

Figure 3. Electrophysiological characteristics and synaptic responses of a stellate cell. All traces were recorded from the cell illustrated in Figure $1 J-L . A$ illustrates the passive membrane properties of a stellate cell and the lack of action potentials during the injection of a family of current pulses. $B$, Stimulation (single pulse, $300 \mu \mathrm{sec}$ ) of the pituitary stalk (arrow) evoked a postsynaptic response consisting of an initial depolarization (420 msec) and a long-lasting hyperpolarization (45 sec). The graded nature of the response could be observed when the stimulation intensity (SI) was varied $(0.5,1.0,1.5,4 \mathrm{~V}) . C$, Current pulses $(100 \mathrm{msec}, 200 \mathrm{pA}, 0.5 \mathrm{~Hz}$ ) were injected during stalk stimulation (SI of $6 \mathrm{~V}$ ) (arrow). The voltage deflections do not indicate a change in resistance during the long-lasting hyperpolarization. $D$, The expanded time base illustrates the initial rapid depolarization following stalk stimulation (SI of $6 \mathrm{~V}$ ).

an initial, small-amplitude depolarization (duration of $<500$ msec, $2-5 \mathrm{mV}$ ) followed by a hyperpolarizing response of much greater amplitude (up to $50 \mathrm{mV}$ ) and duration (up to $75 \mathrm{sec}$ ) ( $n$ $=45$; Figs. $2 B, 3$ ). The latency of the initial GABA response was $8.9 \pm 0.4 \mathrm{msec}$ and peak amplitude was reached in $21.5 \pm$ $1.2 \mathrm{msec}(n=3)$, which was comparable to values observed in melanocytes (latency, $7.7 \pm 0.3 \mathrm{msec}$; time to peak, $21.5 \pm 1.2$ msec; $n=7)$. Although the input resistance was decreased in melanocytes during the initial GABA-mediated IPSP and increased slightly during the dopamine-mediated hyperpolarization, input resistance changes were not observed in the stellate cells following a single-pulse stimulus. When a stimulus train paradigm was used, however, a $45 \%$ decrease in the input resistance was observed (two of two cells) during the depolarizing response (Fig. 4). This was not due to membrane rectification since input resistance changes were not observed when DC current was injected to depolarize the stellate cell membrane to

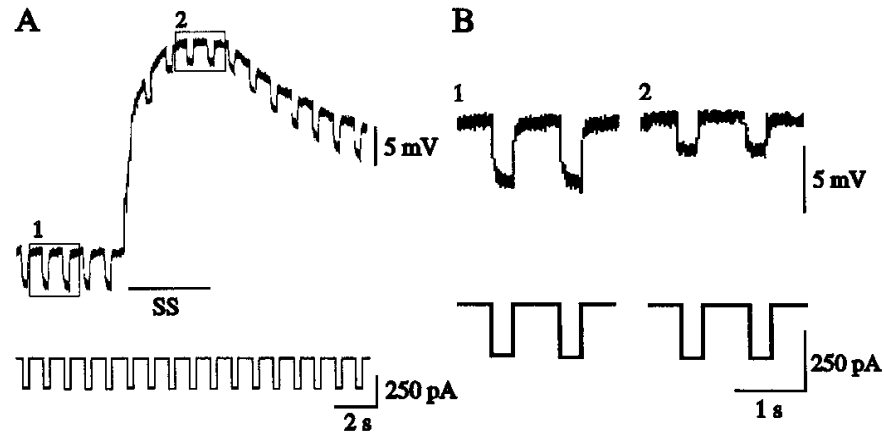

Figure 4. Resistance change in a stellate cell during the synaptic response. $A$ shows the depolarizing postsynaptic response to repetitive stalk stimulation ( $S S ; 1 \mathrm{msec}$ pulse width, $10 \mathrm{~V}, 20 \mathrm{~Hz}, 4 \mathrm{sec}$ duration). Responses were evoked in the presence of sulpiride (see Fig. 8 for details). This stimulus paradigm produced a great increase in both amplitude and duration of the depolarizing response. Constant amplitude current pulses during stalk stimulation showed a decrease in input resistance (observed in two of two cells). Boxes in $A$ are enlarged in $B$. The left panel shows the voltage changes due to current injection prior to stalk stimulation; the right panel shows the voltage changes due to current injection during and after stalk stimulation. The input resistance decreased approximately $46 \%$.

$-20 \mathrm{mV}$ (data not shown). Both the depolarization and the hyperpolarization recorded from the stellate cells were greater in magnitude when the stimulus intensity was increased (Fig. 3).

\section{Synaptic pharmacology}

Since the major neurotransmitters known to be present in the rat pars intermedia are dopamine and GABA (Björklund et al., 1973; Douglas and Taraskevich, 1978; Vincent et al., 1982; MacVicar and Pittman, 1986; Williams et al., 1989a,b), the role of these neurotransmitters in generating the stellate cell response to stalk stimulation was investigated. Picospritzer application of GABA (1 mM; Fig. $5 A$ ) caused a depolarization similar to the initial rapid response following stalk stimulation $(n=15)$. Dopamine application ( $1 \mathrm{~mm}$ ) caused a prolonged hyperpolarization similar to the long-lasting response following stalk stimulation $(n=19)$. These responses persisted in low-Ca ${ }^{2+} /$ high$\mathrm{Mg}^{2+}$ aCSF $(n=5)$, which abolished the synaptic responses completely (Fig. $5 B$ ), and were unaffected by the presence of 3 $\mu \mathrm{M}$ TTX $(n=3$; data not shown).

To determine the pharmacological nature of the receptors responsible for mediating the stellate cell response to stalk stimulation, antagonists of GABAergic and dopaminergic transmission were used. Application of bicuculline $(100 \mu \mathrm{M}), \mathrm{a} \mathrm{GABA}_{\mathrm{A}}$ antagonist, blocked completely the initial depolarizing response to stalk stimulation but did not affect the hyperpolarizing response ( $n=13$; Fig. 6 ). The responses returned to control levels when bicuculline was washed out with control aCSF. Application of sulpiride $(2 \mu \mathrm{M})$, a dopamine $\mathrm{D}_{2}$ antagonist, reduced both the amplitude $(48.7 \pm 6.9 \%)$ and duration $(62.6 \pm 1.2)$ of the long-lasting hyperpolarizing response to stalk stimulation without affecting the depolarizing component ( $n=4$; Fig. $7 A$ ). The responses returned to control levels after washout with control aCSF. Domperidone (10 $\mu \mathrm{M})$, a highly specific $\mathrm{D}_{2}$ antagonist, reduced to a similar degree the amplitude $(36.6 \pm 5.5 \%)$ and duration $(48.5 \pm 3.3 \%)$ of the hyperpolarization due to stalk stimulation ( $n=5$; Fig. $7 B$ ).

Since it was possible that the changes in membrane potential 


\section{A CONTROL}

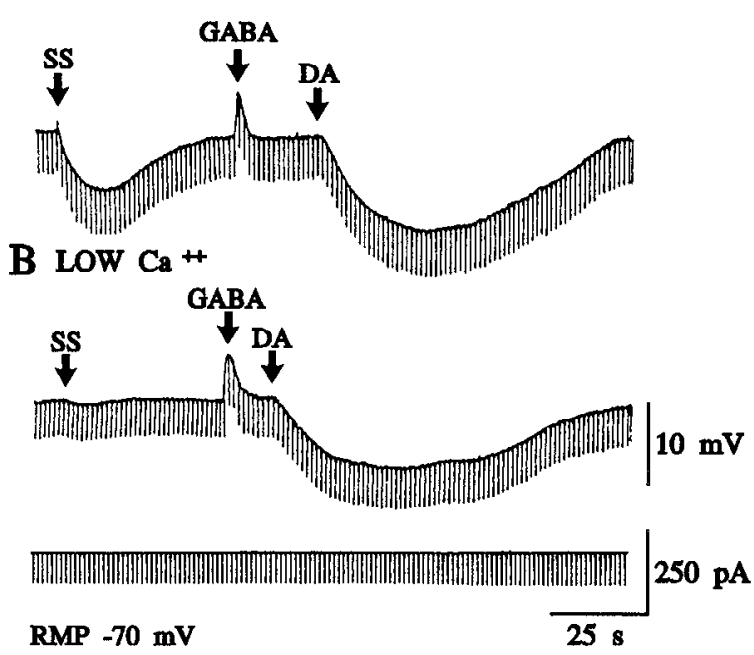

Figure 5. Stellate cell membrane voltage responses to stalk stimulation $(S S)$ and exogenous application of GABA and dopamine $(D A) . A$, In control solution the components of the postsynaptic response evoked by stalk stimulation were mimicked by picospritzer application of GABA (1 $\mathrm{mm}$ ) and dopamine $(1 \mathrm{~mm}) . B$, When the synaptic response was abolished by the application of low- $\mathrm{Ca}^{2+} / \mathrm{high}-\mathrm{Mg}^{2}$ ( $\left(\mathrm{LOWC \textrm {Ca } ^ { \prime }}\right.$ ) $\mathrm{aCSF}$, the response to GABA and dopamine application persisted. Lower trace indicates the current pulses injected throughout the experiment.

observed after afferent stimulation or neurotransmitter application might be due to electrogenic uptake mechanisms, two uptake inhibitors were tested. Nipecotic acid $(10 \mu \mathrm{M})$, an inhibitor of GABA uptake, did not affect the rapid dcpolarizing response to stalk stimulation in preparations where bicuculline was able to abolish this response ( $n=7$; data not shown). GBR $12909(15 \mu \mathrm{M})$, an inhibitor of dopamine uptake, in some cases prolonged the duration of the hyperpolarizing response but the amplitude was affected minimally in preparations where $2 \mu \mathrm{M}$ sulpiride was effective in diminishing this response dramatically $(n=6$; Fig. 7C).

\section{Discussion}

Intracellular recordings were made from identified stellate glial cells of the pituitary pars intermedia, and both depolarizing and hyperpolarizing short-latency changes in membrane potential were observed following a single-pulse stimulus to afferent fibers. The stellate cells of the pars intermedia are similar anatomically to other macroglia of the CNS and, like astrocytes, they possess numerous radiating processes that are in close association with both nerve fibers and principle cells (Stoeckel et al., 1981; Weatherhead, 1983). Extensive dye coupling was observed after neurobiotin injections, suggesting the presence of a glial syncytium, and in agreement with earlier reports (Stoeckel et al., 1981; Ordronneau and Petrusz, 1986), the cells contained GFAP, which is the predominant protein of intermediate filaments in astrocytes. Stellate cells also possess electrophysiological characteristics that are typical of macroglia (reviewed in Walz, 1989). The resting membrane potential of stellate cells is approximately $40 \mathrm{mV}$ more negative than that of the surrounding melanocytes, they have passive membranes in that they do not fire action potentials spontaneously or when injected with current (at these membrane potentials), and their input resistance is low (usually $<40 \mathrm{~m} \Omega$ ), possibly due to their numerous
A
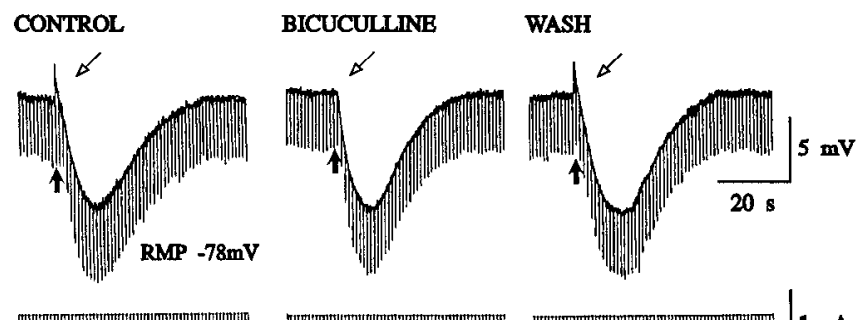

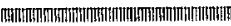

IM:

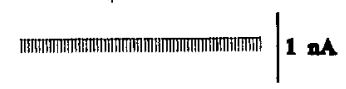

B

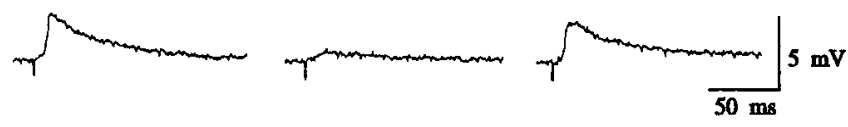

Figure 6. Effect of bicuculline on the synaptic response of stellate cells. $A$, The CONTROL panel illustrates the postsynaptic response to stalk stimulation (solid arrows indicate stimulus train). Bath application of $B I C U C U L L I N E(100 \mu \mathrm{M})$ for 5 min blocked the initial depolarizing response completely (open arrows). The response recovered following washout $(W A S H)$ of bicuculline with control aCSF. Lower traces indicate the current pulses injected during the experiment. $B$, An expanded time scale illustrates more clearly the blockade of the depolarizing response by bicuculline (single-pulse stimulus) in the same cell as in $A$ (left , CONTROL; middle, BICUCULLINE; right, WASH). The latency of this response was $8.3 \mathrm{msec}$, and peak amplitude was reached in 14.3 msec.

processes and extensive coupling. Although it is true that glial cells have many voltage-activated conductances (Barres et al., 1990; Tse et al., 1992; Duffy and MacVicar, 1993) glial membranc propcrties typically appear passive when recordings are obtained with sharp microelectrodes (Burnard et al., 1990). This may be due to the high $\mathrm{K}^{+}$permeability of glial cell membranes at resting potentials. Action potentials have been recorded occasionally from glial cells in specific regions (e.g., spinal cord; Sontheimer et al., 1992) but only under conditions in which $\mathrm{K}^{+}$ permeability had been reduced pharmacologically (MacVicar, 1984; Newman, 1985).

The data from the present study show that these stellate glial cells of the pars intermedia exhibit synaptic potentials in response to stimulation of the axons descending from the arcuate nucleus in the pituitary stalk. These synaptic responses are graded and consist of two components: a rapid depolarization followed by a long-lasting hyperpolarization. The rapid depolarization was blocked by bicuculline and mimicked by picospritzer application of GABA, suggesting that the response was mediated by $\mathrm{GABA}_{\mathrm{A}}$ receptors. The long-lasting hyperpolarization was mimicked by picospritzer dopamine application and the hyperpolarization was blocked substantially by dopamine $D_{2}$ receptor antagonists. The drug concentrations necessary for GA$B A_{A}$ and dopamine $D_{2}$ receptor blockade were 10 -fold higher than those used typically in the CNS. This is most likely due to the extensive syncytium formed by the stellate cells and the problem of slow drug diffusion, deep into the pars intermedia tissue, for complete blockade.

It is not yet known what mediates the small hyperpolarizing component not blocked by the dopamine $\mathrm{D}_{2}$ receptor antagonists. Although there is some cholinergic innervation in the pars intermedia, it is poorly developed and $\mathrm{AChE}$ does not have a distribution related to synaptic function (primarily in the nucleus and rough endoplasmic reticulum; Stoeckel et al., 1981; Weatherhead, 1983). Stoeckel et al. (1981) also report that in 
A

Figure 7. Effect of $\mathrm{D}_{2}$ antagonists and a dopamine uptake inhibitor on the biphasic synaptic response of stellatc cclls. $A-C$, The CONTROL panels illustrate the postsynaptic response to stalk stimulation. $A$, Bath application of $S U L$ PIRIDE $(2 \mu \mathrm{M})$ decreased both the duration $(65 \%)$ and amplitude $(28 \%)$ of the hyperpolarization. The response recovered after washout $(W A S H)$ with control aCSF. $B$, Upper trace, fast time scale; lower trace, slow time scale. $B I$ CUCULLINE (100 $\mu \mathrm{M}, 6 \mathrm{~min})$ blocked the initial depolarization but did not affect the long-lasting hyperpolarization. DOMPERIDONE $(10 \mu \mathrm{M}, 25$ $\mathrm{min}$ ), in the presence of bicuculline, decreased the duration (54\%) and amplitude $(26 \%)$ of the hyperpolarization but did not block it completely. $C$, $G B R 12909(15 \mu \mathrm{M})$, an inhibitor of dopamine uptake, decreased the amplitude of the postsynaptic response minimally (13\%) and prolonged the duration of the response slightly (3\%). SULPIR$I D E$ again diminished the hyperpolarizing response in the presence of GBR 12909
CONTROL
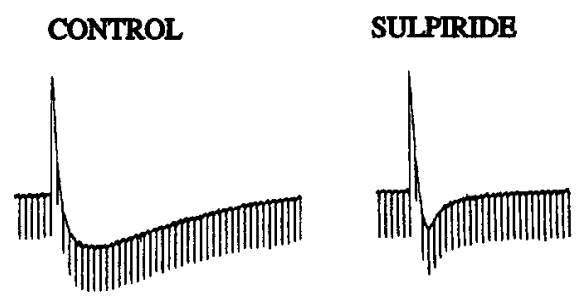

B

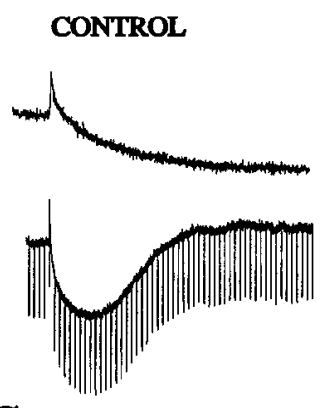

C

CONTROL

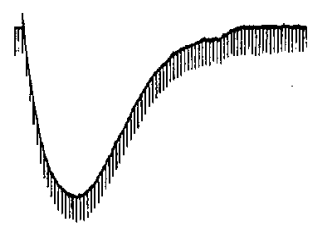

BICUCULLINE

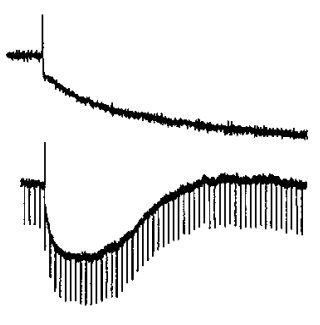

GBR12909

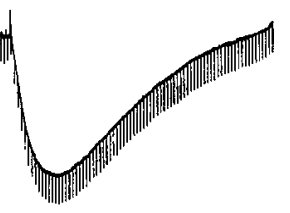

WASH

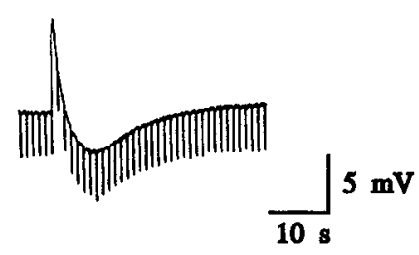

DOMPERIDONE

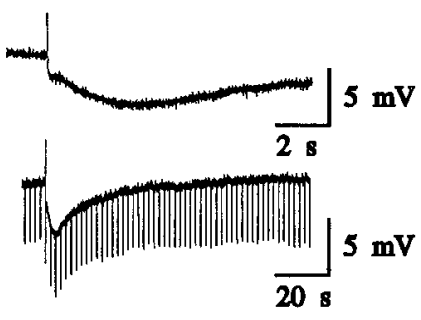

SULPIRIDE

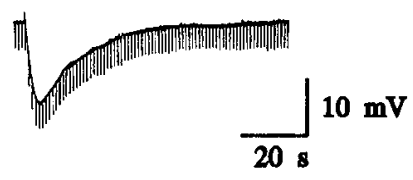

the rat, peptidergic fibers rarely penetrate the pars intermedia. Molecular cloning techniques have now identified at least five dopamine receptor subtypes $\left(D_{1 A}, D_{2}, D_{3}, D_{4}, D_{5} / D_{1 B}\right)$ (Niznik and Van Tol, 1992). Although subtypes other than $D_{2}$ have not yet becn localized in the pituitary pars intermedia, molecular biological analysis may show that other subtypes are present that could underlie the remaining hyperpolarizing component. The lack of specific antagonists makes this possibility difficult to test at present with pharmacological methods.

The responses evoked by GABA and dopamine application persisted in low- $\mathrm{Ca}^{2+} /$ high- $\mathrm{Mg}^{2+}$ aCSF and in the presence of TTX. This suggested that these responses were the result of direct transmitter action on the postsynaptic cell and not mediated indirectly by an action on presynaptic nerve terminals or on adjacent melanocytes. Although it is possible that the neurotransmitter pool mediating the stellate cell response following stalk stimulation may have arisen by diffusion from melanocyte synapses, it is unlikely given the short latency of the depolarizing GABA response. Furthermore, Williams et al. (1992) were not able to detect dopamine concentrations following single-pulse or low-frequency repetitive stimuli within 100 $\mu \mathrm{m}$ of an electrochemistry electrode. Since synaptic contacts do exist between the stellate cells and axons from the arcuate nucleus, it is more likely that the responses are postsynaptic.

Inhibitors of GABA and dopamine uptake, nipecotic acid and GBR 12909, respectively, did not affect the synaptic response, which demonstrated that the responses were not due to electrogenic uptake of the neurotransmitters. Furthermore, sulpiride not only blocks $D_{2}$ dopamine receptors but also increases do- pamine release from the presynaptic terminals in this preparation by $100 \%$ (Williams et al., 1992). If the response was due to electrogenic uptake, the amplitude and duration of the response would have increased following sulpiride application. The response decreased substantially following sulpiride application, demonstrating that the response was postsynaptic and not due to electrogenic neurotransmitter uptake.

$\mathrm{GABA}_{\mathrm{A}}$ receptors are present on a variety of glial cells and activation of these receptors has been shown to produce a depolarization in cultured oligodendrocytes (Gilbert et al., 1984), cultured astrocytes (Kettenmann et al., 1984), Müller cells (Malchow et al., 1989), glial cells in hippocampal slices (Constantini and Galvan, 1978; Walz and MacVicar, 1988; MacVicar et al., 1989), and more recently in acutely isolated hippocampal astrocytes (Duffy et al., 1992). This depolarization is most likely due to a $\mathrm{Cl}^{-}$conductance because the $\mathrm{GABA}_{\mathrm{A}}$ receptor is coupled to a chloride channel. The $\mathrm{Cl}^{-}$equilibrium potential is more positive than the resting membrane potential in macroglia and, therefore, $\mathrm{a} \mathrm{CI}^{-}$efflux probably underlies the depolarization (Kettenmann et al., 1987). In some stellate cells a conductance incrcase was observed during the GABA-mediated depolarization, which supports the notion of a $\mathrm{Cl}^{-}$efflux.

Dopamine receptors have also been reported to be present on cultured astrocytes (Henn et al., 1980; Hansson et al., 1984), and application of dopamine produces a membrane hyperpolarization in these cells (Hösli and Hösli, 1988). Pharmacological evidence suggests that this effect is mediated by the $D_{2}$ dopamine receptor subtype. In other cell types including melanocytes, activation of this receptor subtype has been associated 
with the opening of a potassium channel (Lacey et al., 1987; Freedman and Weight, 1988; Williams et al., 1989b). However, a conductance change was not obscrved during the synaptic or dopamine evoked hyperpolarization. It is possible that the gap junctions of the electrically coupled syncytium shunted the transmitter-mediated conductances. It may be possible in future experiments to identify more definitively the ionic conductances underlying the effects of GABA and dopamine by using acutely isolated stellate cells that would not retain a glial syncytium.

It is well known that both GABA and dopamine can reduce action potential frequency and $\alpha$-melanocyte-stimulating hormone release from melanocytes (Tilders et al., 1975; Douglas and Taraskevich, 1978; Tomiko et al., 1983). Although speculative, synaptic modulation of glial $\mathrm{Cl}^{-}$and $\mathrm{K}^{+}$permeability could regulate both extracellular homeostasis and melanocyte excitability and thereby play and integral role in the regulation of hormone release from the pars intermedia.

\section{References}

Aoki C (1992) $\beta$-Adrenergic receptors: astrocytic localization in the adult visual cortex and their relation to catecholamine axon terminals as revealed by electron microscopic immunocytochemistry. J Neurosci 12:781-792.

Barres BA, Chun LLY, Corey DP (1990) Ion channels in vertebrate glia. Annu Rev Neurosci 13:441-474.

Baumgarten HG, Björklund A, Holstein AFD, Nobin A (1972) Organization and ultrastructural identification of the catecholamine nerve terminals in the neural lobe and pars intermedia of the rat pituitary. Z Zellforsch Mikrosk Anat 126:483-575.

Björklund A, Moore RY, Nobin A, Stenevi U (1973) The organization of tubero-hypophyseal and reticulo-infundibular catecholamine neuron systems in the rat brain. Brain Res 51:171-191.

Bosler O, Beaudet A, Denoroy L (1987) Electron-microscopic characterization of adrenergic axon terminals in the diencephalon of the rat. Cell Tissue Res 248:393-398.

Burnard DM, Crichton SA, MacVicar BA (1990) Electrophysiological properties of reactive glial cells in the kainate-lesioned hippocampal slice. Brain Res 510:43-52.

Card JP, Moore RY (1985) Axo-glial contacts in the median eminence of the rat: ultrastructural and immunohistochemical observations. Anat Rec 211:32A-33A.

Clark B, Mobbs P (1992) Transmitter-operated channels in rabbit retinal astrocytes studied in situ by whole-cell patch clamping. I Neurosci 12:664-673.

Constantini A, Galvan M (1978) Amino acid-evoked depolarization of clectrically inexcitable (neuroglial?) cells in the guinea-pig olfactory cortex slice. Brain Res 153:183-187.

Cull-Candy SG, Wyllie DJA (1991) Glutamate-receptor channels in mammalian glial cells. Ann NY Acad Sci 633:458-474.

de Rijk EPCT, Jenks BG, Vaudry H, Roubos EW (1990) GABA and neuropeptide $\mathrm{Y}$ co-exist in axons innervating the neurointermediate lobe of the pituitary of Xenopus laevis - an immunoelectron microscopic study. Neuroscience 38:495-502.

Douglas WW, Taraskevich PS (1978) Action potentials in gland cells of rat pituitary pars intermedia: inhibition by dopamine, an inhibitor of MSH secretion. J Physiol (Lond) 285:171-184.

Douglas WW, Taraskevich PS (1980) Calcium component to action potentials in rat pars intermedia cells. J Physiol (Lond) 309:623-630.

Duffy S, MacVicar BA (1993) Voltage-activated ionic channels in astrocytes. In: Astrocytes (Murphy S, ed), pp 137-169. San Diego: Academic.

Duffy S, Fraser DD, Hoppe D, Kettenmann H, MacVicar BA (1992) Pharmacological properties of $\mathrm{GABA}_{\mathrm{A}}$ receptor of acutely isolated hippocampal astrocytes. Soc Neurosci Abstr 18:785.

Eng LF (1985) Glial fibrillary acidic protein (GFAP): the major protein of glial intermediate filaments in differentiated astrocytes. J Neuroimmunol 8:203-214.

Evans PD, Reale V, Merzon RM, Villegas J (1990) Substance P modulation of the membrane potential of the Schwann cell of the squid giant nerve fibre. Glia 3:393-404.
Freedman JE, Weight $\mathrm{FF}$ (1988) Single $\mathrm{K}^{+}$channels activated by dopamine $\mathrm{D}_{2}$ receptors in acutely dissociated neurons from rat corpus striatum. Proc Natl Acad Sci USA 85:3618-3622.

Gilbert P, Kettenmann H, Schachner M (1984) Gamma-aminobutyric acid directly depolarizes cultured oligodendrocytes. J Neurosci 4:561569.

Hansson E, Rönnbäck L, Sellström $\AA$ (1984) Is there a "dopaminergic glial cell'? Neurochem Res 9:679-689.

Harumitsu H, Slater NT, Kimelberg HK (1983) $\alpha$-Adrenergic receptor-mediated depolarization of rat neocortical astrocytes in primary culture. Brain Res 270:358-362.

Henn FA, Decring J, Andcrson DJ (1980) Receptor studies on isolated astroglial cell fractions prepared with and without trypsin. Neurochem Res 5:459-464.

Hirata H, Slater NT, Kimelberg HK (1983) $\alpha$-Adrenergic receptormediated depolarization of rat neocortical astrocytes in primary culture. Brain Res 270:358-362.

Hösli L, Hösli E (1988) Electrophysiologic and autoradiographic evidence for receptors for biogenic amines on astrocytes in explant cultures of rat CNS. In: Glial cell receptors (Kimmelberg HK, ed), pp 77-93. New York: Raven.

Hösli L, Hösli E, Zehntner C, Lehmann R, Lutz TW (1982) Evidence for the existence of $\alpha$ - and $\beta$-adrenoceptors on cultured glial cellsan electrophysiological study. Neuroscience 7:2867-2872.

Jahromi BS, Robitaille R, Charlton MP (1992) Transmitter release increases intracellular calcium in perisynaptic Schwann cells in situ. Neuron 8:1069-1077.

Kettenmann H, Backus KH, Schachner M (1984) Aspartate, glutamate, and gamma-aminobutyric acid depolarize cultured astrocytes. Neurosci Lett 52:25-29.

Kettenmann H, Backus KH, Schachner M (1987) $\gamma$-Aminobutyric acid opens $\mathrm{Cl}^{-}$channels in cultured astrocytes. Brain Res 404:1-9.

Lacey MG, Mercuri NB, North RA (1987) Dopamine acts on $D_{2}$ receptors to increase potassium conductance in neurons of the rat substantia nigra zona compacta. J Physiol (Lond) 392:397-416.

Leranth C, Feher E (1983) Synaptology and sources of vasoactive intestinal polypeptide (VIP) and substance P (SP) containing axons of the cat celiac ganglion. An experimental electron microscopic immunohistochemical study. Neuroscience 10:947-958.

Licbcrman EM, Abbott NJ, Hassan S (1989) Evidence that glutamate mediates axon-to-Schwann cell signaling in the squid. Glia 2:94-102.

MacVicar BA (1984) Voltage-dependent calcium channels in glial cells. Science 226:1345-1347.

MacVicar BA, Pittman QJ (1986) Novel synaptic responses mediated by dopamine and $\gamma$-aminobutyric acid in neuroendocrine cells of the intermediate pituitary. Neurosci Lett 64:35-40.

MacVicar BA, Tse FWY, Crichton SA, Kettenmann H (1989) GABAactivated $\mathrm{Cl}^{-}$channels in astrocytes of hippocampal slices. J Neurosci 9:3577-3583.

Malchow RP, Qian H, Ripps H (1989) $\gamma$-Aminobutyric acid (GABA)induced currents of skate Müller (glial) cells are mediated by neuronal-

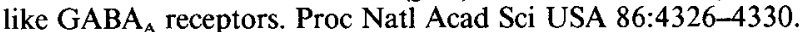

Marrero H, Astion ML, Coles JA, Orkand RK (1989) Facilitation of voltagc-gatcd ion channcls in frog neuroglia by nerve impulses. Nature 339:379-380.

Newman EA (1985) Voltage-dependent calcium and potassium channels in retinal glial cells. Nature 317:809-811.

Niznik HB, Van Tol HHM (1992) Dopamine receptor genes: new tools for molecular psychiatry. J Psychiatr Neurosci 17:158-180.

Oertel WH, Mugnaini E, Tappaz ML, Weise VK, Dahl A, Schmechel DE, Kopin IJ (1982) Central GABAergic innervation of neurointermediate pituitary lobe: biochemical and immunocytochemical study in the rat. Proc Natl Acad Sci USA 79:675-679.

Ordronneau P, Petrusz P (1986) Non-hormonal markers in the pituitary. In: Immunocytochemistry: modern methods and applications (Polak JM, VanNoorden S, eds), pp 425-437. London: Wright.

Reist NE, Smith SJ (1992) Neurally evoked calcium transients in terminal Schwann cells at the ncuromuscular junction. Proc Natl Acad Sci USA 89:7625-7629.

Rønnekleiv OK, Loose MD, Erickson KR, Kelly MJ (1990) A method for immunocytochemical identification of biocytin-labeled neurons following intracellular recording. Biotechniques 9:432-438.

Schmechel D, Marangos PJ, Brightman M (1978) Neurone-specific enolase is a molecular marker for peripheral and central neuroendocrine cells. Nature 276:834-836. 
Sontheimer H, Kettenmann H, Backus KH, Schachner M (1988) Glutamate opens NA/K channels in cultured astrocytes. Glia 1:328-336.

Sontheimer H, Black JA, Ransom BR, Waxman SG (1992) Ion channels in spinal cord astrocytes in vitro. I. Transient expression of high levels of $\mathrm{Na}^{+}$and $\mathrm{K}^{+}$channels. J Neurophysiol 68:985-1000.

Stoeckel ME, Schmitt G, Porte A (1981) Fine structure and cytochemistry of the mammalian pars intermedia. CIBA Found Symp 81:101-127.

Taraskevich PS, Douglas WW (1982) GABA directly affects electrophysiological properties of pituitary pars intermedia cells. Nature 299: 733-734.

Tilders FJH, Mulder AH, Smelik PG (1975) On the presence of a MSH-release inhibiting system in the rat neurointermediate lobe. Neuroendocrinology 19:125-130.

Tomiko SA, Taraskevich PS, Douglas WW (1983) GABA acts directly on cells of pituitary pars intermedia to alter hormone output. Nature 301:706-707.

Tse FWY, Fraser DD, Duffy S, MacVicar BA (1992) Voltage-activated $\mathrm{K}^{+}$channels in acutely isolated hippocampal astrocytes. $\mathrm{J}$ Neurosci 12:1781-1788.

Usowicz MM, Gallo V, Cull-Candy SG (1989) Multiple conductance channels in type- 2 cerebellar astrocytes activated by excitatory amino acids. Nature 339:380-383.

Vincent SR, Hökfelt T, Wu J (1982) GABA neuron systems in hypothalamus and the pituitary gland. Neuroendocrinology 34:117-125.
Walz W (1989) Role of glial cells in the regulation of the brain ion microenvironment. Prog Neurobiol 33:309-333.

Walz W, MacVicar BA (1988) Electrophysiological properties of glial cells. Comparison of brain slices with primary cultures. Brain Res 443:321-324.

Weatherhead B (1983) The pars intermedia of the pituitary gland. In: Progress in anatomy, Vol 3 (Navarabraham V, Harrison RJ, eds), pp 1-32. New York: Cambridge UP.

Williams PJ, MacVicar BA, Pittman QJ (1989a) Identification of a GABA-activated chloride-mediated synaptic potential in rat pars intermedia. Brain Res 483:130-134.

Williams PJ, MacVicar BA, Pittman QJ (1989b) A dopaminergic inhibitory postsynaptic potential mediated by an increased potassium conductance. Neuroscience 31:673-681.

Williams PJ, Dunwiddie TV, Gerhardt G (1992) Direct in vitro electrochemical measurement of dopamine overflow in intermediate pituitary: characterization and pharmacology. J Pharmacol Exp Ther 261:403-411.

Wingstrand KG (1966) Microscopic anatomy, nerve supply and blood supply of the pars intermedia. In: The pituitary gland, Vol 3, Pars intermedia and neurohypophysis (Harris GW, Donovan B', eds), pp 1-27. London: Butterworth. 